\title{
The absence of corpus luteum formation alters the endocrine profile and affects follicular development during the first follicular wave in cattle
}

\author{
Ken-Go Hayashi ${ }^{1}$, Motozumi Matsui ${ }^{2}$, Takashi Shimizu${ }^{1}$, Natsuko Sudo ${ }^{1}$, Ayako Sato ${ }^{1}$, \\ Koumei Shirasuna ${ }^{1}$, Masa Tetsuka ${ }^{3}$, Katsuya Kida ${ }^{4}$, Dieter Schams ${ }^{5}$ and Akio Miyamoto ${ }^{1}$ \\ ${ }^{1}$ Graduate School of Animal and Food Hygiene, ${ }^{2}$ Department of Clinical Veterinary Science, ${ }^{3}$ Department of \\ Agricultural and Life Science and ${ }^{4}$ Field Center of Animal Science and Agriculture, Obihiro University of Agriculture \\ and Veterinary Medicine, Obihiro 080-8555, Japan and ${ }^{5}$ Institute of Physiology, Technical University of Munich, \\ Freising-Weihenstephan 85350, Germany
}

Correspondence should be addressed to M Matsui; Email: mmatsui@obihiro.ac.jp

K-G Hayashi is now at Reproductive Biology Research Unit, National Institute of Agrobiological Sciences, Tsukuba, Ibaraki 305-8602, Japan

\begin{abstract}
We previously established a bovine experimental model showing that the corpus luteum $(\mathrm{CL})$ does not appear following aspiration of the preovulatory follicle before the onset of LH surge. Using this model, the present study aimed to determine the profile of follicular development and the endocrinological environment in the absence of $C L$ with variable nadir circulating progesterone $\left(P_{4}\right)$ concentrations during the oestrous cycle in cattle. Luteolysis was induced in heifers and cows and they were assigned either to have the dominant follicle aspirated (CL-absent) or ovulation induced (CL-present). Ultrasound scanning to observe the diameter of each follicle and blood collection was performed from the day of follicular aspiration or ovulation and continued for 6 days. The CL-absent cattle maintained nadir circulating $\mathrm{P}_{4}$ throughout the experimental period and showed a similar diameter between the largest and second largest follicle, resulting in co-dominant follicles. Oestradiol $\left(\mathrm{E}_{2}\right)$ concentrations were greater in the $\mathrm{CL}$-absent cows than in the $\mathrm{CL}$-present cows at day -1 , day 1 and day 2 from follicular deviation. The CL-absent cows had a higher basal concentration, area under the curve (AUC), pulse amplitude and pulse frequency of LH than the CL-present cows. After follicular deviation, the CL-absent cows showed a greater basal concentration, AUC and pulse amplitude of growth hormone $(\mathrm{GH})$ than the $\mathrm{CL}$-present cows. These results suggest that the absence of $\mathrm{CL}$ accompanying nadir circulating $\mathrm{P}_{4}$ induces an enhancement of $\mathrm{LH}$ pulses, which involves the growth of the co-dominant follicles. Our results also suggest that circulating levels of $\mathrm{P}_{\mathbf{4}}$ and $E_{2}$ affect pulsatile $\mathrm{GH}$ secretion in cattle.

Reproduction (2008) 136 787-797
\end{abstract}

\section{Introduction}

Monovular species including cattle have a restricted ovulation quota; therefore, selection of the dominant follicle is the most drastic event during follicular development to decide its fertility. Follicular selection is characterized by the appearance of differences in growth rate between a future dominant follicle and future subordinate follicles in the same cohort, termed follicular deviation (Ginther et al. 1997). In cattle, deviation occurs when the largest follicle reaches an average of $8.5 \mathrm{~mm}$ in diameter (Ginther et al. 1996). Although the detailed mechanisms of follicular selection have not been completely clarified, recent studies indicate that specific changes of the intrafollicular insulin-like growth factor (IGF) system and the enhanced capacity of oestradiol $\left(E_{2}\right)$ production in the future dominant follicle play a critical role in the selection of a dominant follicle accompanied by a decline of circulating follicle-stimulating hormone (FSH) towards the nadir level (Austin et al. 2001, Rivera \& Fortune 2001).

Increasing evidence suggests that progesterone $\left(\mathrm{P}_{4}\right)$ secreted from the corpus luteum $(\mathrm{CL})$ has a regulatory effect on follicular selection and on the number of dominant follicles in cattle. $\mathrm{P}_{4}$ is a crucial factor to negatively regulate pulsatile luteinizing hormone $(\mathrm{LH})$ release from the pituitary gland and inhibits maturation and ovulation of the dominant follicle during the bovine oestrous cycle (Kinder et al. 1996). Administration of $\mathrm{P}_{4}$ to decline circulating $\mathrm{LH}$ concentrations decreases the diameter of the dominant follicle and its ability to produce $E_{2}$ during first follicular wave in cattle (Ginther et al. 2001a). In addition, several studies suggest that $\mathrm{P}_{4}$ secreted from the $\mathrm{CL}$ may have a regulatory role in the mechanism of follicular selection through modulation of $\mathrm{LH}$ secretion in cattle. It has been 
reported that cows that developed co-dominant follicles during the first follicular wave had a lower $\mathrm{P}_{4}$ concentration and a higher $\mathrm{LH}$ concentration than cows that developed a single dominant follicle (Lopez et al. 2004). The incidence of co-dominant follicles increased in the first follicular wave with developing $\mathrm{CL}$ rather than in the second follicular wave with the mature CL (Kulick et al. 2001). However, because there is still no suitable experimental model, the effect on the dynamics of follicular development by altering the $\mathrm{LH}$ pulse when $\mathrm{P}_{4}$ secretion from the $\mathrm{CL}$ is completely suppressed during the oestrous cycle in cattle is not known.

Growth hormone $(\mathrm{GH})$ is known as one of the important modulators for follicular development by acting both directly and indirectly, in combination, via the liver IGF1 (Lucy 2000). Exogenous GH treatment in cows increases the number of recruited follicles, and as a result, there is an increase in the number of growing follicles (Gong et al. 1993a, Kirby et al. 1997, Jimenez-Krassel et al. 1999). Several studies examined the release of $\mathrm{GH}$ during the oestrous cycle of goats (Yonezawa et al. 2005) and sheep (Landefeld \& Suttie 1989), in which the release of GH was suppressed at the luteal phase and stimulated at the follicular phase according to the changes in circulating steroid hormone levels. On the other hand, these studies also indicated the effect of exogenous steroid hormone treatment on GH release (Landefeld \& Suttie 1989, Yonezawa et al. 2005), where treatment of $E_{2}$ or $P_{4}$ for ovariectomized goats altered the $\mathrm{GH}$ secretory pattern: $\mathrm{GH}$ pulsatility was enhanced by $E_{2}$ and inhibited by $P_{4}$ (Yonezawa et al. 2005). In addition, a long-term (45 days) treatment of $E_{2}$ in ovariectomized cows showed an increase in the plasma $\mathrm{GH}$ concentration and an amplitude in the GH pulse (Simpson et al. 1997). These studies suggest that sex steroid hormones $\left(\mathrm{P}_{4}\right.$ and $\left.\mathrm{E}_{2}\right)$ from the ovary have the ability to modulate pulsatile secretion of $\mathrm{GH}$ and that this feedback system may involve the regulation of ovarian function. However, it is not known whether this hypothesis applies to the oestrous cycle in cattle. In addition, an increase in the circulating IGF1 concentrations at the follicular phase has been reported in goats (Yonezawa et al. 2005) and cattle (Kawashima et al. 2007b). Since GH directly affects IGF1 secretion, changes in secretion pattern of steroid hormones during the oestrous cycle may alter not only GH pulsatility but also IGF1 secretion.

Recently, we established a bovine experimental model that showed the suppression of $\mathrm{CL}$ formation and continuance of nadir circulating $\mathrm{P}_{4}$ concentrations for approximately 1 week following the aspiration of the preovulatory follicle at the follicular phase (Hayashi et al. 2006). To our knowledge, this is the first experimental model to completely suppress the development of $\mathrm{CL}$ during the oestrous cycle in cattle. By using this experimental model, the present study aimed to determine the profile of follicular development and endocrinological environment $\left(\mathrm{P}_{4}, \mathrm{E}_{2}, \mathrm{FSH}\right.$, $\mathrm{LH}$ pulse, $\mathrm{GH}$ pulse and total IGF1) in the absence of $\mathrm{CL}$ with nadir circulating $\mathrm{P}_{4}$ concentrations during the oestrous cycle in cattle. We hypothesized that the absence of $\mathrm{CL}$ formation during the first follicular wave alters the endocrine profile and affects follicular development; thus, the first follicular wave following follicular aspiration (CL-absent) was compared with the first follicular wave following ovulation during the oestrous cycle (CL-present). In experiment 1, we observed the differences of follicular diameter and circulating $\mathrm{P}_{4}$ and $E_{2}$ concentrations during the first follicular wave between the CL-absent and CL-present heifers and cows. In experiment 2, we determined the profiles of circulating $\mathrm{P}_{4}, \mathrm{E}_{2}, \mathrm{FSH}$, total IGF1 and the pulsatile release of $\mathrm{LH}$ and $\mathrm{GH}$ during the perifollicular deviation period in the CL-absent and CL-present cows.

\section{Results}

In both experiments 1 and 2, induction of luteolysis by prostaglandin $\mathrm{F}_{2 \alpha}\left(\mathrm{PGF}_{2 \alpha}\right)$ injection was observed using transrectal ultrasound scanning by monitoring ovulation in the CL-present group and by follicular aspiration in the $\mathrm{CL}$-absent group, thereby confirming luteolysis in all animals used in this study. Ovulation and subsequent $\mathrm{CL}$ formation by gonadotrophin-releasing hormone (GNRH) injection following $\mathrm{PGF}_{2 \alpha}$ treatment were induced in all CL-present animals. In experiment 2, one CL-absent cow was removed from the study because this cow did not develop co-dominant follicles.

\section{Experiment 1}

\section{Follicular diameter at day 3 and day 6}

In the CL-present cows (Fig. 1A), the diameter of the largest follicle (F1) and the second largest follicle (F2) was similar at day $3(\mathrm{~F} 1,9.9 \pm 0.8 ; \mathrm{F} 2,7.8 \pm 0.7 \mathrm{~mm})$ but the diameter of $\mathrm{F} 1$ was greater than that of $\mathrm{F} 2$ at day 6 (F1, $14.6 \pm 0.5 ; F 2,7.5 \pm 0.8 \mathrm{~mm})$. In the CL-absent cows, $\mathrm{F} 1$ and $\mathrm{F} 2$ showed a similar diameter at both day 3 $(\mathrm{F} 1,8.2 \pm 0.9 ; \mathrm{F} 2,7.3 \pm 0.9 \mathrm{~mm})$ and day $6(\mathrm{~F} 1,12.9 \pm 0.7$; $\mathrm{F} 2,11.2 \pm 1.1 \mathrm{~mm}$ ) after follicular aspiration. In heifers (Fig. 1B), as well as in cows, the diameter of F1 was greater than that of $\mathrm{F} 2$ in the $\mathrm{CL}$-present heifers at day 6 (F1, $11.9 \pm 0.3 ; \mathrm{F} 2,7.1 \pm 0.6 \mathrm{~mm}$ ) but there was no difference in diameter between $\mathrm{F} 1$ and $\mathrm{F} 2$ in the $\mathrm{CL}$-absent heifers $(F 1,11.7 \pm 0.7 ; F 2,9.8 \pm 1.0 \mathrm{~mm})$. As shown in Table 1, the number of CL-absent cattle that developed co-dominant follicles at day 6 was four out of five in both cows and heifers, including one cow and one heifer that showed double ovulation. At day 9, the number of $\mathrm{CL}$-absent cattle showing double ovulation was four out of five cows and two out of five heifers.

\section{Changes in plasma $P_{4}$ and $E_{2}$ concentrations during first follicular wave}

Figure 2 shows changes in the plasma $\mathrm{P}_{4}$ concentrations in cows (Fig. 2A), $\mathrm{P}_{4}$ concentrations in heifers (Fig. 2B) and $E_{2}$ concentrations in heifers (Fig. 2C). Plasma $P_{4}$ 

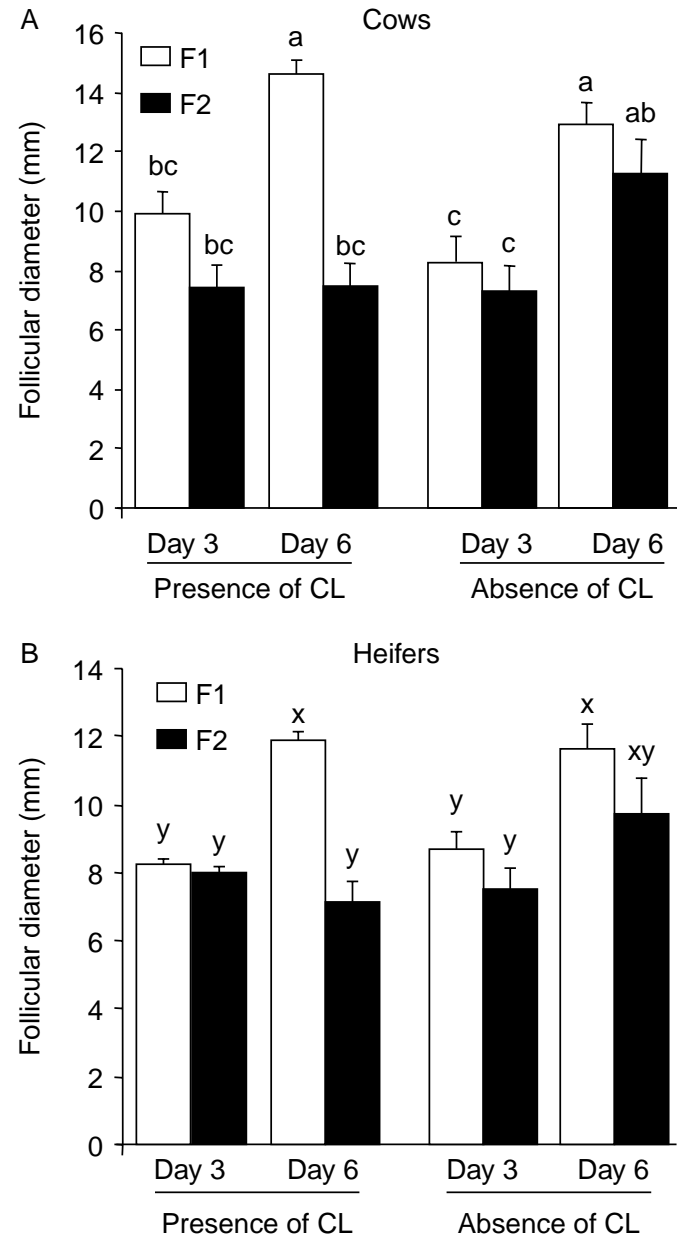

Figure 1 Mean follicular diameter of two largest follicles (F1, largest follicle; F2, second largest follicle) for (A) cows and (B) heifers at day 3 and day 6 . Day 0 was defined as the day of follicular aspiration for the CL-absent groups (cows, $n=5$; heifers, $n=5$ ) or the day of ovulation for the CL-present groups (cows, $n=5$; heifers, $n=3$ ). Data are shown as the mean \pm S.E.M. of each time period. a, b, c: Values with different letters are significantly different within cows $(P<0.05)$. $x, y$ : Values with different letters are significantly different within heifers $(P<0.05)$.

concentrations in cows and heifers, and $E_{2}$ concentrations in heifers showed an interaction between group and day $(P<0.01)$. The $\mathrm{CL}$-absent cows had a lower $\mathrm{P}_{4}$ concentration than the $\mathrm{CL}$-present cows at days 3 and $6(P<0.05)$. The $\mathrm{CL}$-absent heifers had a lower $\mathrm{P}_{4}$ concentration than the $\mathrm{CL}$-present heifers after the second half of day 1 $(P<0.05)$, and had a greater $\mathrm{E}_{2}$ concentration than the $\mathrm{CL}$-present heifers during the second half of day 4 and the first half of day $5(P<0.05)$.

\section{Experiment 2}

\section{Characteristics of follicular dynamics during first} follicular wave

In the CL-absent cows, follicular deviation occurred 2 days after the follicular aspiration in two cows and 3 days after aspiration in the other two cows. In the
CL-present cows, follicular deviation occurred the day following ovulation in two cows and 2 days after ovulation in the remaining two cows.

Figure 3 shows the profile of follicular growth in the CL-absent and CL-present cows from day -1 to day 2 by daily ultrasound observation. In the $\mathrm{CL}$-absent cows (Fig. 3A), follicular diameter in F1 was not significantly different from that in F2 from day -1 to day 2, resulting in co-dominant follicles. Following follicular deviation, the diameter of F1 and F2 was greater than that in F3 and F4 $(P<0.05)$, and that of F2 in the $\mathrm{CL}$-absent cows was greater than that of the $\mathrm{CL}$-present cows $(P<0.05)$. The diameter of F1, F2, F3 and F4 at day 2 was $11.8 \pm 0.4$, $11.2 \pm 0.2,7.3 \pm 0.6$ and $4.9 \pm 0.1 \mathrm{~mm}$ respectively. In the $\mathrm{CL}$-present cows (Fig. 3B), the diameter of F1 was greater than that of F2, F3 and F4 after follicular deviation $(P<0.05)$; thus, only $\mathrm{F} 1$ continued to grow as a dominant follicle. The diameter of F1, F2, F3 and $\mathrm{F} 4$ at day 2 was $12.0 \pm 0.1,7.6 \pm 0.8,6.3 \pm 0.5$ and $5.6 \pm 0.6 \mathrm{~mm}$ respectively.

Changes in plasma $P_{4}, E_{2}$ and $F S H$ concentrations during first follicular wave

Figure 4 shows changes in the plasma $\mathrm{P}_{4}$ concentrations (Fig. 4A), $\mathrm{E}_{2}$ concentrations (Fig. 4B) and FSH concentrations (Fig. 4C). Plasma $\mathrm{P}_{4}$ and $\mathrm{E}_{2}$ concentrations showed an interaction between group and day $(P<0.05)$. The $\mathrm{CL}$-absent cows had a lower $\mathrm{P}_{4}$ concentration than the $\mathrm{CL}$-present cows after day 0 $(P<0.05)$. The $\mathrm{E}_{2}$ concentration of the $\mathrm{CL}$-absent cows was greater than that of the $\mathrm{CL}$-present cows in the second half of day -1 , the second half of day 0 and the first half of day 1 and day $2(P<0.05)$. Plasma FSH concentrations showed only a main effect of day $(P<0.01)$.

\section{Characteristics of $\mathrm{LH}$ pulses during first follicular wave}

Figure 5 shows the characteristics of the $\mathrm{LH}$ pulses during the first follicular wave in the CL-absent and CL-present cows. Mean LH concentrations (data not shown) showed a main effect of group $(P<0.05)$ and tended to show a main effect of day $(P<0.06)$. The $\mathrm{CL}$-absent cows had greater mean $\mathrm{LH}$ concentrations than the $\mathrm{CL}$-present cows during the experimental period (CL-absent, $2.0 \pm 0.04 \mathrm{ng} / \mathrm{ml}$; CL-present, $1.6 \pm 0.06 \mathrm{ng} / \mathrm{ml} ; \quad P<0.01)$. Basal LH

Table 1 The number of corpus luteum (CL)-absent cattle that showed co-dominant follicles and double ovulation in experiment 1 .

\begin{tabular}{lccc}
\hline & $\boldsymbol{n}$ & $\begin{array}{c}\text { Co-dominant } \\
\text { follicles at day 6 }\end{array}$ & $\begin{array}{c}\text { Double } \\
\text { ovulation by } \\
\text { day } \mathbf{9}\end{array}$ \\
\hline Cows & 5 & $4^{\mathrm{a}}$ & 4 \\
Heifers & 5 & $4^{\mathrm{a}}$ & 2
\end{tabular}

${ }^{\mathrm{a}}$ One cow and one heifer already showed double ovulation. Day $0=$ day of follicular aspiration. 

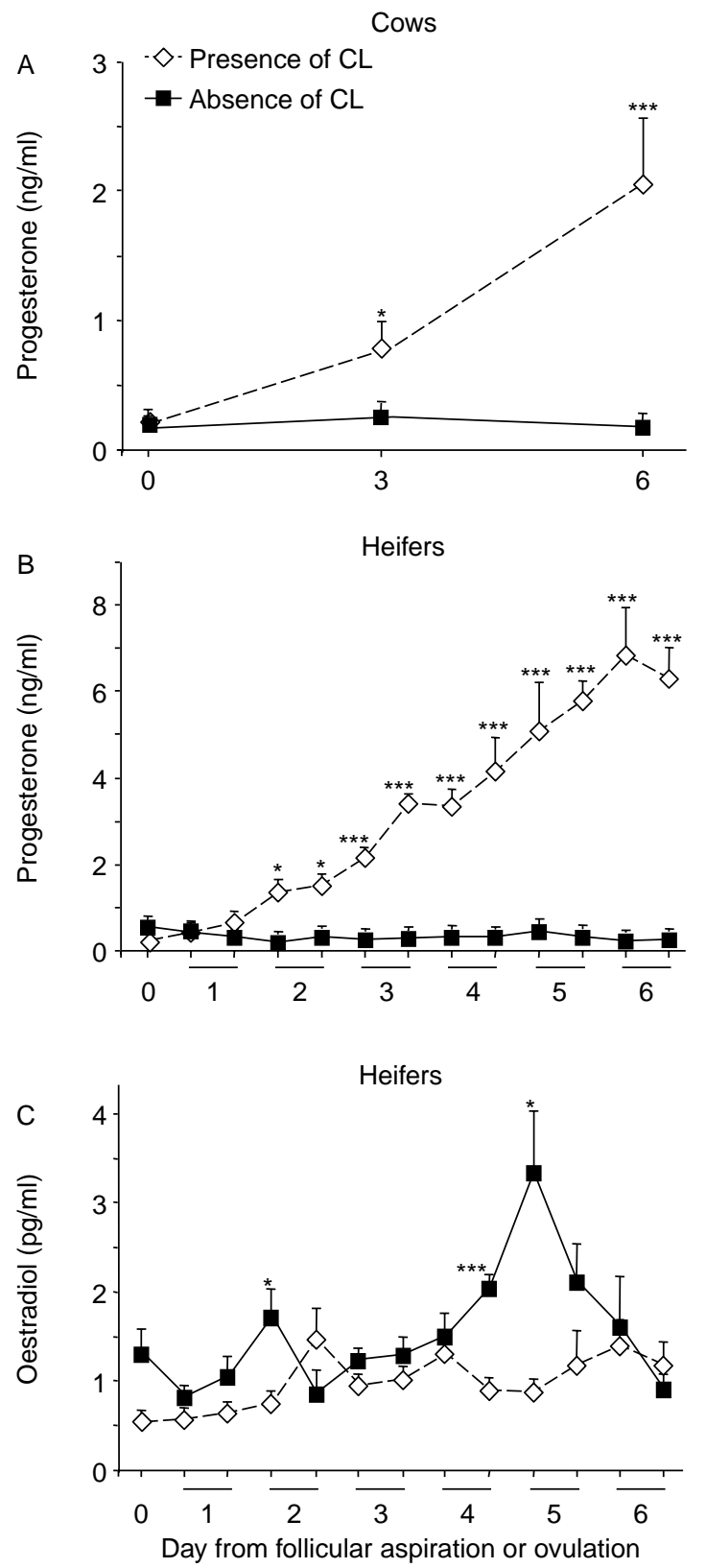

Figure 2 Changes in the plasma concentrations of (A) progesterone for cows, (B) progesterone for heifers and (C) oestradiol for heifers. Blood samples were collected every 3 days in cows and twice daily in heifers from the day of follicular aspiration for the CL-absent group (cows, $n=5$; heifers, $n=5$ ) or the day of ovulation for the CL-present group (cows, $n=5$; heifers, $n=3$ ). Data are shown as the mean \pm s.E.M. of each time period. A significant interaction between group and day was observed in all data. Asterisks indicate significant differences between groups $\left(* P<0.05,{ }^{* * *} P<0.001\right)$.

concentrations (Fig. 5A) showed a main effect of group $(P<0.05)$ and tended to show a main effect of day $(P<0.06)$. The $\mathrm{CL}$-absent cows had a greater basal LH concentration than the CL-present cows during the experimental period $(P<0.01)$. LH pulse amplitude (Fig. 5B) tended to show an interaction between group and day $(P<0.1)$. The $\mathrm{CL}$-absent cows had a higher $\mathrm{LH}$
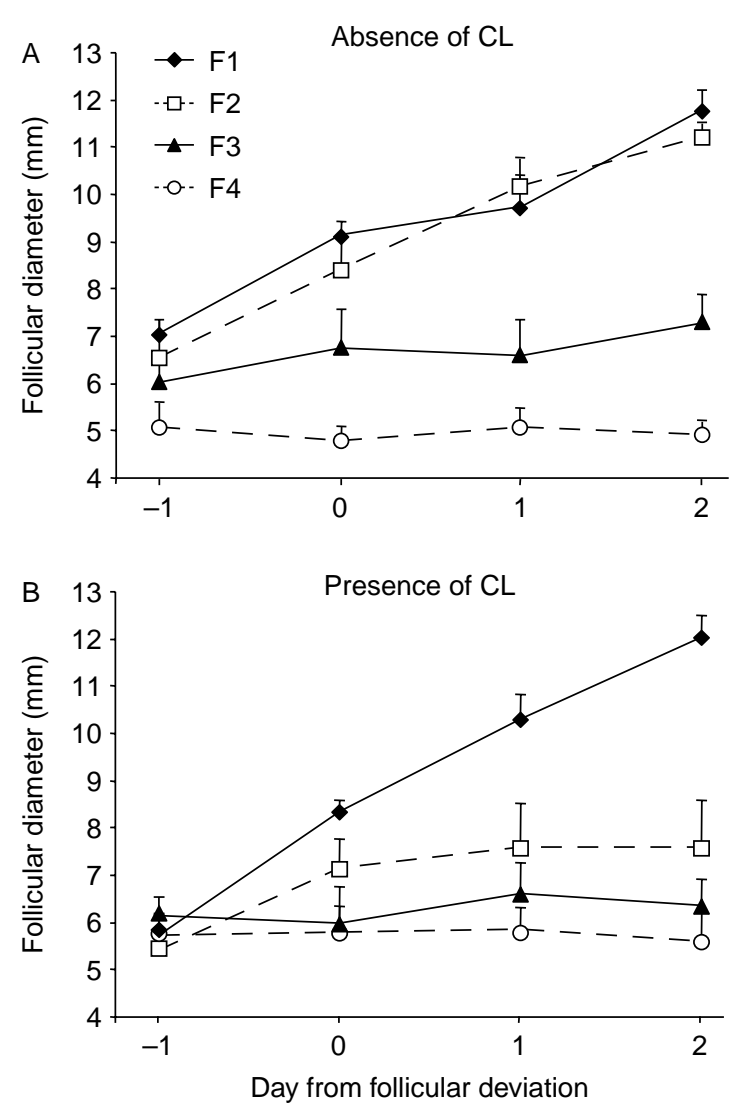

Figure 3 Follicular profiles of the four largest follicles for (A) CL-absent and (B) CL-present cows. Transrectal ultrasound scanning was performed daily from the day of follicular aspiration for the CL-absent cows $(n=4)$ or the day of ovulation for the CL-present cows $(n=4)$. Data were normalized to the day of follicular deviation (day 0 ) and are shown as the mean \pm s.E.M. of each time period. In the CL-absent cows, the diameter of F2 was not different as compared with F1 from day -1 to day 2. In addition, the diameter of F1 and F2 was greater than F3 and F4 at day 1 and day $2(P<0.05)$. In the $C L$-present cows, diameter of F1 was greater than that of F2, F3 and F4 at day 1 and day $2(P<0.05)$. The $\mathrm{CL}$-absent cows had greater $\mathrm{F} 2$ than the $\mathrm{CL}$-present cows at day 1 $(P<0.05)$ and day $2(P<0.01)$.

pulse amplitude than the CL-present cows at day -1 and day $1(P<0.05)$. LH pulse frequency (Fig. $5 \mathrm{C})$ tended to show a main effect of group $(P<0.1)$. The $\mathrm{CL}$-absent cows had a higher $\mathrm{LH}$ pulse frequency than the $\mathrm{CL}$-present cows during the experimental period $(P<0.05)$. Area under the curve (AUC; Fig. 5D) showed a main effect of group $(P<0.05)$ and tended to show a main effect of day $(P<0.08)$. The $\mathrm{CL}$-absent cows had a higher $A \cup C$ than the $\mathrm{CL}$-present cows during the experimental period $(P<0.01)$.

\section{Characteristics of GH pulses during first follicular wave}

Representative $8 \mathrm{~h}$ plasma $\mathrm{GH}$ profiles in the $\mathrm{CL}$-absent and CL-present cows are shown in Fig. 6. Figure 7 shows the characteristics of the $\mathrm{GH}$ pulses during the first follicular wave in the CL-absent and CL-present cows. Mean $\mathrm{GH}$ concentrations (data not shown) tended to 

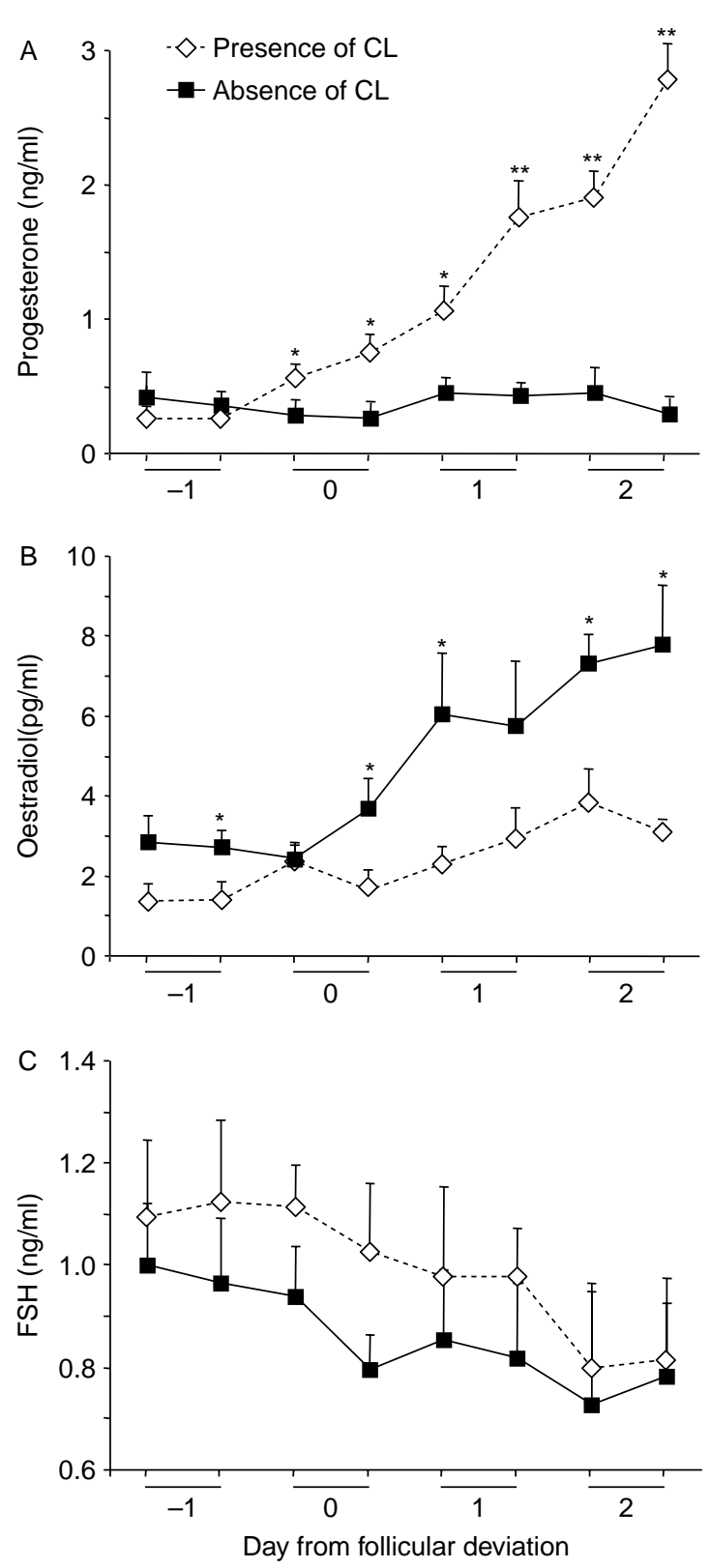

Figure 4 Changes in plasma concentration of (A) progesterone, (B) oestradiol and (C) FSH for the CL-absent and CL-present cows. Blood samples were collected twice daily from the day of follicular aspiration for the $\mathrm{CL}$-absent cows $(n=4)$ or the day of ovulation for the CL-present cows $(n=4)$. Data were normalized to the day of follicular deviation (day 0 ) and are shown as the mean \pm s.E.M. of each time period. A significant interaction between group and day was observed in progesterone and oestradiol. No significant interaction between group and day was observed in FSH. Asterisks indicate significant differences between groups $\left({ }^{*} P<0.05,{ }^{* *} P<0.01\right)$.

show a main effect of group $(P<0.07)$. The $C L$-absent cows had a greater mean $\mathrm{GH}$ concentration than the $\mathrm{CL}$-present cows during the experimental period (CLabsent, $13.0 \pm 0.8 \mathrm{ng} / \mathrm{ml}$; CL-present, $9.6 \pm 0.8 \mathrm{ng} / \mathrm{ml}$; $P<0.01$ ). Basal GH concentrations (Fig. 7A) tended to show an interaction between group and day $(P<0.1)$.
The CL-absent cows had a greater basal GH concentration than the $\mathrm{CL}$-present cows at days 1 and 2 $(P<0.05)$. GH pulse amplitude (Fig. $7 \mathrm{~B})$ showed an interaction between group and day $(P<0.05)$. The $\mathrm{CL}$-absent cows had a higher $\mathrm{GH}$ pulse amplitude than the $\mathrm{CL}$-present cows at days 0 and $1(P<0.07)$. GH pulse frequency (Fig. $7 C$ ) showed neither a main effect of group and day nor their interaction. AUC (Fig. 7D) tended to show an interaction between group and day $(P<0.1)$. The $\mathrm{CL}$-absent cows had a higher AUC than the $\mathrm{CL}$-present cows at day 1 and day $2(P<0.05)$.

\section{Changes in plasma total IGF1 concentration during first follicular wave}

Changes in the plasma total IGF1 concentrations are shown in Fig. 8. Plasma total IGF1 concentrations showed an interaction between group and day $(P<0.01)$. Although there was no significant difference in the plasma total IGF1 concentration between the two groups, it increased in the $\mathrm{CL}$-absent cows on the first half of day 2 compared with the first half of day 0 , and the second half of day 2 compared with day -1 and the first half of day $0(P<0.05)$.

\section{Discussion}

The significant findings of this study were that: i) the absence of $C L$ during the first follicular wave induced the development of co-dominant follicles and double ovulation and ii) $\mathrm{GH}$ secretion such as the basal concentration, pulse amplitude and $\mathrm{AUC}$ of $\mathrm{GH}$, and plasma total IGF1 concentration increased under a circulating level of nadir $\mathrm{P}_{4}$ and high $\mathrm{E}_{2}$.

A high incidence $(80 \%)$ of co-dominant follicles was observed in the CL-absent cows and heifers. We also observed double ovulation within 9 days from follicular aspiration in all cows and half the heifers developed co-dominant follicles in experiment 1 . Thus, our results suggest that both dominant follicles were healthy and had an ovulatory capacity in most of the CL-absent cattle. Our present results are consistent with a recent study in which the high incidence of co-dominant follicles was observed in the contralateral remaining ovary when the corpus haemorrhagicum was removed soon after ovulation (Gumen \& Wiltbank 2005).

LH pulse amplitude was higher in the CL-absent cows than in the CL-present cows at day -1 , whereas plasma $\mathrm{P}_{4}$ concentrations did not differ between the two groups. Since the $\mathrm{CL}$-absent cows had higher plasma $\mathrm{E}_{2}$ concentrations in the second half of day $-1(P<0.05)$ and a greater tendency than the $\mathrm{CL}$-present cows in diameter of $\mathrm{F} 1(P<0.06)$ at day $-1, E_{2}$ secreted from $\mathrm{F} 1$ may stimulate $\mathrm{LH}$ secretion in the $\mathrm{CL}$-absent cows at day -1 . To support this, treatment with $\mathrm{E}_{2}$ benzoate increases the amplitude and basal concentrations of LH pulses in cattle (Austin et al. 2002). In addition, a second possibility could be considered that pituitary stores of LH and sensitivity to GNRH might differ 

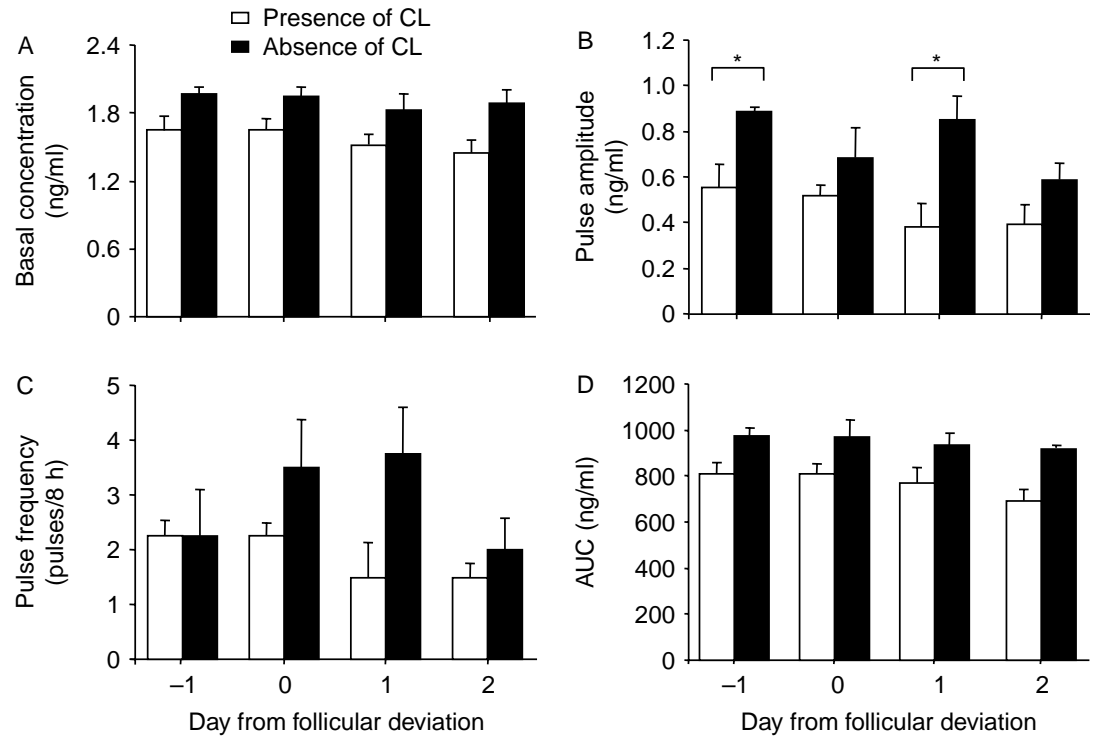

Figure 5 Characteristics of $\mathrm{LH}$ pulses in the CL-absent and CL-present cows. (A) Basal concentration, (B) pulse amplitude, (C) pulse frequency and (D) area under the curve (AUC). Data were normalized to the day of follicular deviation (day 0 ) and are shown as the mean \pm s.E.M. of each time period. Tendency of interaction between group and day was observed in pulse amplitude $(P<0.1)$. No significant interaction was observed for other data. Basal concentration, pulse frequency and $\mathrm{AUC}$ were greater in the $\mathrm{CL}$-absent cows during experimental period compared with the CL-present cows. Asterisks indicate significant differences between groups $(P<0.05)$. as a result of cows in the $\mathrm{CL}$-present group experiencing an LH surge in the previous 2 days, whereas follicular aspiration presumably blocked the $\mathrm{LH}$ surge in the $\mathrm{CL}$-absent cows. An increase in the circulating $\mathrm{E}_{2}$ concentration and follicular diameter in the CL-absent cows at day -1 suggests a more rapid growth of follicles in these cows than the CL-present cows. It is well documented that FSH plays a critical role in bovine follicular development before selection, and is especially closely associated with an alteration of the intrafollicular IGF1 system to promote $\mathrm{E}_{2}$ production (Rivera \& Fortune 2003). Lopez et al. (2004) reported that cows that develop multiple dominant follicles show an increase in circulating $\mathrm{FSH}$ and $\mathrm{E}_{2}$ concentrations before follicular deviation. Therefore, although there was no difference in plasma FSH concentrations between the two groups from day -1 to day 2, FSH may contribute to the development of co-dominant follicles.
One of the key characteristics of follicular selection is the acquisition of an $\mathrm{LH}$ receptor in granulosa cells. However, there are various reports about the timing of the acquisition of the $\mathrm{LH}$ receptor by granulosa cells during bovine follicular development (Xu et al. 1995, Bao et al. 1997, Evans \& Fortune 1997, Beg et al. 2001). On the other hand, there was no difference in the $\mathrm{LH}$ receptor mRNA expression in theca cells between future dominant follicle and future subordinate follicles before follicular selection (Xu et al. 1995, Bao et al. 1997, Evans \& Fortune 1997). Thus, it seems that theca cells of both F1 and F2 might be able to respond to $\mathrm{LH}$ before follicular deviation in the $\mathrm{CL}$-absent cattle. In the present study, the basal $\mathrm{LH}$ concentration, pulse frequency and AUC of LH were greater in the $\mathrm{CL}$-absent cows than in the $\mathrm{CL}$-present cows during the experimental period. Several studies demonstrated that LH is involved in follicular selection, and that the incidence of co-dominant follicles is closely associated

A CL-present (cow \#285)
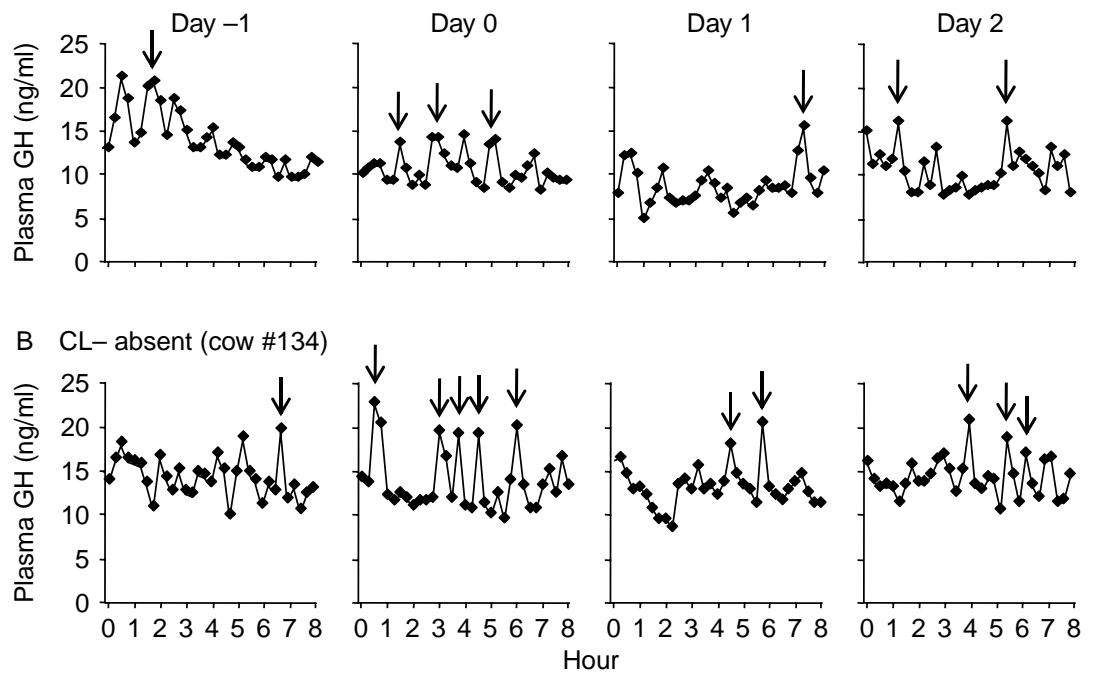

Figure 6 Individual representative $8 \mathrm{~h}$ plasma $\mathrm{GH}$ profiles in the (A) CL-present and (B) CL-absent cows. Arrows indicate $\mathrm{GH}$ pulses. 

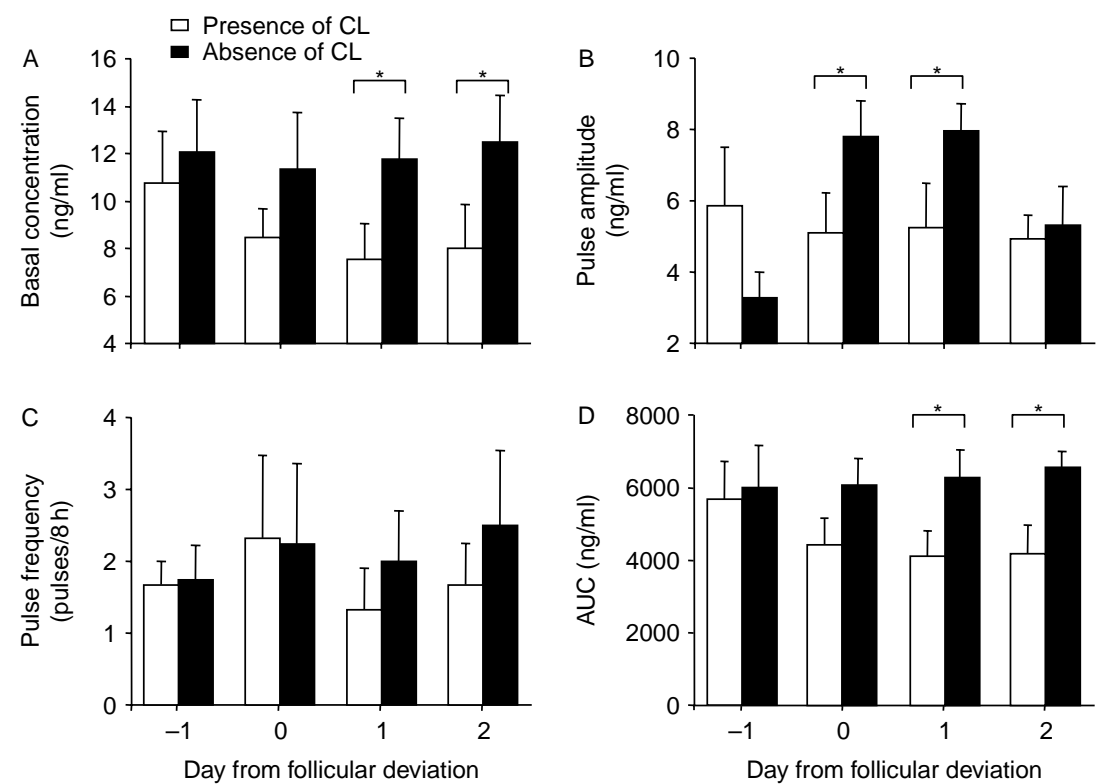

Figure 7 Characteristics of $\mathrm{GH}$ pulses in the CL-absent and CL-present cows. (A) Basal concentration, (B) pulse amplitude, $(C)$ pulse frequency and (D) area under the curve (AUC). Data were normalized to the day of follicular deviation (day 0) and are shown as the mean \pm s.E.M. of each time period. Tendency of interaction between group and day was observed in basal concentrations and AUC $(P<0.1)$. Interaction between group and day was observed in pulse amplitude $(P<0.05)$. No significant interaction between group and day was observed in pulse frequency. Asterisks indicate significant differences between groups $(P<0.05)$.

with an increase in the level of circulating $\mathrm{LH}$ during the bovine follicular wave (Ginther et al. 1998, Kulick et al. 1999, 2001, Lopez et al. 2004). Suppression of LH secretion by $\mathrm{P}_{4}$ treatment at the time of follicular deviation decreases follicular $E_{2}$ and free IGF1 concentrations and increases IGF-binding protein 2 (IGFBP2) concentration in the follicular fluid of the dominant follicle (Ginther et al. 2001 b). Pulsatile LH infusion into GNRH agonist-treated cows and during the follicular wave of cyclic cows demonstrated that the $\mathrm{LH}$ is required for $\mathrm{mRNA}$ expression of steroidogenic enzymes in both granulosa and theca cells, which is responsible for a dramatic increase in the follicular fluid concentration of $E_{2}$ and further follicular growth (Crowe et al. 2001, Manikkam et al. 2001, Hampton et al. 2004). We postulated that enhanced $\mathrm{LH}$ pulses in the CL-absent cows permit accelerated F2 growth and thus stimulate $\mathrm{E}_{2}$ production. Hence, $\mathrm{F} 2$ would reach a dominant status and override follicular selection together with $\mathrm{F} 1$, resulting in the development of co-dominant follicles.

A previous study that used ovariectomized goats indicated that $E_{2}$ treatment enhanced the $\mathrm{GH}$ pulse amplitude and $A \cup C$, whereas treatment with $\mathrm{P}_{4}$ reduced them (Yonezawa et al. 2005). Our present results showed that the basal $\mathrm{GH}$ concentration and AUC of $\mathrm{GH}$ increased at days 1 and 2, and the pulse amplitude increased at days 0 and 1 in the CL-absent cows more than in the CL-present cows. These changes of pulsatile $\mathrm{GH}$ release in the $\mathrm{CL}$-absent cows were observed in accordance with the appearance of differences in plasma $\mathrm{P}_{4}$ and $\mathrm{E}_{2}$ levels between the two groups, suggesting that the $\mathrm{GH}$ secretory profiles were altered by the circulating levels of ovarian sex steroid hormones. Therefore, our results strongly suggest that the ovarian sex steroid hormones have the ability to modulate pulsatile pattern of $\mathrm{GH}$ secretion in cows.
In the present study, there were no differences in the plasma total IGF1 concentration between the CL-absent cows and the CL-present cows; however, it increased after rather than before follicular deviation in the $\mathrm{CL}$-absent cows. An increase in the total IGF1 concentration under circulating levels of high $\mathrm{E}_{2}$ and nadir $\mathrm{P}_{4}$ after selection of co-dominance in the CL-absent cows is similar to an increase in the circulating total IGF1 at the follicular phase during the bovine oestrous cycle (Kawashima etal. 2007 b). In addition, Echternkamp et al. (1990) reported that cattle selected for the birth of twins have a greater IGF1 concentration than cattle not selected for such a birth. It has been reported that bovine liver expresses mRNA for $E_{2}$ receptor, but not $\mathrm{P}_{4}$ receptor (Pfaffl et al. 2002). Thus, an

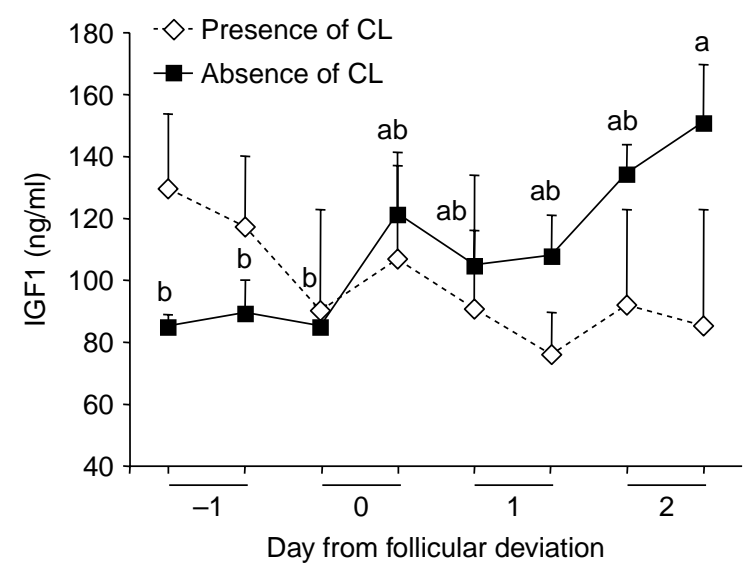

Figure 8 Changes in plasma concentration of total IGF1 for the $\mathrm{CL}$-absent and CL-present cows. Blood samples were collected twice daily from the day of follicular aspiration for the CL-absent cows $(n=4)$ or the day of ovulation for the CL-present cows $(n=4)$. Data were normalized to the day of follicular deviation (day 0 ) and are shown as the mean \pm S.E.M. of each time period. A significant interaction between group and day was observed. a, b: Values with different letters are significantly different within $\mathrm{CL}$-absent cows $(P<0.05)$. 
increase in total IGF1 concentration may be directly induced by high circulating $\mathrm{E}_{2}$ secreted from co-dominant follicles. Additionally, since $\mathrm{GH}$ is known as a potent stimulator of liver IGF1 secretion, enhanced GH pulses in the CL-absent cows would indirectly stimulate an increase in total IGF1 secretion. Previous studies demonstrate that both $\mathrm{GH}$ and IGF1 have the ability to stimulate cell proliferation, steroidogenesis and expression of $\mathrm{LH}$ and FSH receptors in bovine follicular cells (Gong et al. 1993b, 1994, Spicer et al. 1993, Spicer \& Echternkamp 1995, Sirotkin \& Makarevich 1999). Therefore, enhanced GH pulses and increased total IGF1 concentration in the $\mathrm{CL}$-absent cows may contribute to the growth of the co-dominant follicles.

In conclusion, our results suggest that the absence of $\mathrm{CL}$ accompanying nadir circulating $\mathrm{P}_{4}$ during bovine first follicular wave induces the growth of the co-dominant follicles. Nadir circulating $\mathrm{P}_{4}$ concentrations in the $\mathrm{CL}$-absent cattle allow the enhancement of LH pulses, which may be involved in further growth of the second largest follicle together with the largest follicle and the appearance of co-dominance. Our results also showed that a condition of nadir circulating $\mathrm{P}_{4}$ and increased circulating $E_{2}$ enhances the $\mathrm{GH}$ pulses, suggesting that sex steroid hormones from the ovary may affect the regulation of $\mathrm{GH}$ pulsatility in cows.

\section{Materials and Methods}

\section{Animals}

The animal experiment was carried out at the Field Center of Animal Science and Agriculture, Obihiro University, Japan. Experimental procedures complied with the Guide for Care and Use of Agricultural Animals of Obihiro University. Heifers and non-lactating cows were fed twice a day with corn silage, concentrate and timothy hay $(54.1 \%$ dry matter (DM) for total dissolved nitrogen (TDN) and $12.5 \%$ DM for crude protein (CP). The lactating cows were fed twice a day with a total mixed ration consisting of grass, corn silage and concentrate (70.6\% DM for TDN and 14.8\% DM for CP). They had access to water ad libitum.

The animals had at least two oestrous cycles of normal length (21-23 days) before being used in the experiment. In all animals, the existence of $\mathrm{CL}$ in the ovary was confirmed at the mid-luteal stage of the oestrous cycle (10-15 days after oestrus) using transrectal ultrasound scanning; then, they received $500 \mu \mathrm{g}$ of a $\mathrm{PGF}_{2 \alpha}$ analogue (cloprostenol (Estrumate); Schering-Plough Animal Health K.K., Osaka, Japan) i.m. to induce luteolysis.

\section{Experimental procedure}

In both experiments 1 and 2, we set the starting point of the experiment as the time of the beginning of $\mathrm{CL}$ formation. The CL-present group was started from ovulation, and the $\mathrm{CL}$-absent group was started from the time of disappearance of the dominant follicle by follicular aspiration since ovulation does not occur in this group.

\section{Experiment 1}

Ten lactating cows and eight heifers were used and randomly assigned to one of two groups. In the CL-absent cows $(n=5)$ and heifers $(n=5)$, follicular aspiration was performed at $42 \mathrm{~h}$ and $36 \mathrm{~h}$ after $\mathrm{PGF}_{2 \alpha}$ injection respectively. Our previous study confirmed that the dominant follicles were aspirated before exposure to the LH surge (Hayashi et al. 2006). The time of follicular aspiration was different between cows and heifers because some heifers showed oestrus at $42 \mathrm{~h}$ after $\mathrm{PGF}_{2 \alpha}$ injection in a preliminary experiment. In the $\mathrm{CL}$-present cows $(n=5)$ and heifers $(n=3)$, ovulation of the preovulatory follicle was induced by a GNRH analogue (Fertirelin acetate $100 \mu \mathrm{g}$; (Conceral); Schering-Plough Animal Health) injected $48 \mathrm{~h}$ after $\mathrm{PGF}_{2 \alpha}$. Ovulation of the preovulatory follicle was checked by ultrasound scanning, performed at a 24-h interval from the GNRH injection. The day of follicular aspiration (CL-absent groups) or ovulation (CL-present groups) was designated as day 0. Blood samples were obtained from day 0 to day 6 by caudal venipuncture just before each ultrasound scanning every 3 days in cows to determine $\mathrm{P}_{4}$ and twice a day every $12 \mathrm{~h}$ in heifers to determine $P_{4}$ and $E_{2}$. In both groups of cows and heifers, ultrasound scanning to monitor follicles was performed every 3 days at days $0,3,6$ and 9 .

\section{Experiment 2}

In this experiment, we performed frequent blood sampling to analyse the pulsatile release of $\mathrm{LH}$ and $\mathrm{GH}$. Nine non-lactating cows were used. For frequent blood sampling, all cows had a 14-gauge catheter (Argyle CV Catheter Kit; Nippon Sherwood Medical Industries Ltd, Tokyo, Japan) fixed into the jugular vein 2 days before injection of $\mathrm{PGF}_{2 \alpha}$. In the $\mathrm{CL}$-absent cows $(n=5)$, follicular aspiration was performed at $42 \mathrm{~h}$ after injection of $\mathrm{PGF}_{2 \alpha}$. Frequent blood sampling (5 ml) was done every 15 min for successive $8 \mathrm{~h}$ in $24 \mathrm{~h}$ from just after follicular aspiration, and continued for 6 days. In the CL-present cows $(n=4)$, ovulation of the preovulatory follicle was induced by a GNRH analogue injected $48 \mathrm{~h}$ after $\mathrm{PGF}_{2 \alpha}$. For FSH and $\mathrm{E}_{2}$ determination, blood samples $(20 \mathrm{ml}$ ) were collected every $6 \mathrm{~h}$ for $48 \mathrm{~h}$ after injection of GNRH. For determination of the $\mathrm{LH}$ surge, a $5 \mathrm{ml}$ blood collection was done every $2 \mathrm{~h}$ from $2 \mathrm{~h}$ before to $8 \mathrm{~h}$ after GNRH injection. Ovulation of the preovulatory follicle was monitored by transrectal ultrasound scanning, performed at a $6 \mathrm{~h}$ interval from $24 \mathrm{~h}$ after GNRH injection until ovulation was observed. Frequent blood sampling $(5 \mathrm{ml}$ ) began every $15 \mathrm{~min}$ for successive $8 \mathrm{~h}$ in $24 \mathrm{~h}$ from the time point at which ovulation was observed, and continued for 6 days. In both groups, blood collection $(20 \mathrm{ml})$ for determination of $\mathrm{P}_{4}, \mathrm{E}_{2}$ and $\mathrm{FSH}$ was done twice daily for 6 days and transrectal ultrasound scanning was performed daily immediately after the end of the frequent blood sampling for 6 days to monitor the number and diameter of each follicle.

Because the length of the time period from ovulation or follicular aspiration to follicular deviation varied among the cows, all the data (follicular diameter, circulating hormone concentrations and characteristics of $\mathrm{LH}$ and $\mathrm{GH}$ pulses) were normalized to the day of observed deviation based on the criteria established in a previous study (Ginther et al. 1996). The day of follicular deviation was defined as the day of beginning of the greatest difference in growth rates between the largest follicle and 
the second largest follicle in the CL-present cows or between the co-dominant follicles and third largest follicle in the CL-absent cows during the retrospectively identified ultrasound observation. The day of follicular deviation was designated as day 0 .

\section{Follicular aspiration and transrectal ultrasound scanning}

The procedure for follicular aspiration was done as previously described (Hayashi et al. 2006). Briefly, for ultrasound guidance of the aspiration needle, an ultrasound scanner (SSD-5500, Aloka Co., Tokyo, Japan) was equipped with a 7.5 MHz transvaginal convex transducer (UST-M15-21079, Aloka) attached to a stainless steel needle guide. Before follicular aspiration, cows received caudal epidural anaesthesia with $5 \mathrm{ml}$ of $2 \%$ lidocaine ((Xylocaine); AstraZeneca Co., Osaka, Japan) to prevent straining, and then the vulva and perineal area were cleaned. The transvaginal convex transducer was inserted into the vagina, and the ovary containing the targeted follicle was positioned next to the transducer face by rectal manipulation so that the targeted follicle was displayed on the needle path of the monitor. An 18-gauge single-lumen stainless steel needle connected to a $5 \mathrm{ml}$ disposable syringe was pushed into the needle guide and inserted into the antrum of the follicle through the vaginal wall. If the preovulatory follicle could not be identified by ultrasonography, all follicles with a diameter of $\geq 6 \mathrm{~mm}$ were aspirated.

To determine the number and size of developing follicles, the ovaries were scanned by transrectal ultrasonography using an ultrasound scanner (SSD-5500, Aloka) equipped with a $7.5 \mathrm{MHz}$ convex transducer (UST-995-7.5, Aloka) in a standardized procedure as previously described in our laboratory (Acosta et al. 2002, 2005). Co-dominant follicles were defined as the difference in diameter between the F1 and $\mathrm{F} 2$, which was less than $2 \mathrm{~mm}$ at the last day of the experiment.

\section{Hormone determinations}

In both experiments 1 and 2, blood samples were collected using sterile $10 \mathrm{ml}$ tubes containing $200 \mu \mathrm{l}(100 \mu \mathrm{l}$ for frequent sampling in experiment 2) of a stabilizer solution (0.3 M EDTA, $1 \%$ acid acetyl salicylic, $\mathrm{pH} 7.4$ ). All tubes were immediately chilled in ice water, centrifuged at $2000 \mathrm{~g}$ for $15 \mathrm{~min}$ at $4{ }^{\circ} \mathrm{C}$, and the plasma obtained was stored at $-30^{\circ} \mathrm{C}$ until hormone analysis. At the end of the experiment, the concentrations of $\mathrm{P}_{4}$, $\mathrm{E}_{2}, \mathrm{FSH}, \mathrm{LH}, \mathrm{GH}$ and total IGF1 in plasma were determined in duplicate by second-antibody enzyme immunoassay (EIA) using 96-well ELISA plates (Corning Glass Works, Corning, NY, USA). All procedures for each EIA were previously established in our laboratory (Mutayoba et al. 1990, Miyamoto et al. 1992, Watanabe et al. 1997, Acosta et al. 1998, Wijayagunawardane et al. 1998, Kawashima et al. 2007a, 2007c). Steroid hormone assays were carried out after extraction with diethyl ether described previously in our laboratory (Acosta et al. 1998). The extraction efficiency of $E_{2}$ and $P_{4}$ was 80 and $95 \%$ respectively. The EIA for $\mathrm{P}_{4}$ was done as previously described (Miyamoto et al. 1992). The standard curve ranged from 0.05 to $50 \mathrm{ng} / \mathrm{ml}$, and the effective dose $\left(\mathrm{ED}_{50}\right)$ of the assay was $3.2 \mathrm{ng} / \mathrm{ml}$. The intra- and inter-assay coefficients of variation (CV) averaged 6.5 and $9.7 \%$ respectively. The EIA for $\mathrm{E}_{2}$ was carried out as previously described (Wijayagunawardane et al. 1998). The standard curve ranged from 2 to $2000 \mathrm{pg} / \mathrm{ml}$, and the $\mathrm{ED}_{50}$ of the assay was $3.3 \mathrm{pg} / \mathrm{ml}$. The average intra- and inter-assay CVs were 6.3 and $9.5 \%$ respectively. The FSH concentrations were determined directly in duplicate as $30 \mu \mathrm{l}$ plasma samples using a sensitive EIA for FSH determination in bovine plasma based on the streptavidin-biotin technique by a modification of a method previously reported by Watanabe et al. (1997). The standard curve for FSH ranged from 0.18 to $12 \mathrm{ng} / \mathrm{ml}$, and the $\mathrm{ED}_{50}$ of the assay was $1.7 \mathrm{ng} / \mathrm{ml}$. The intra- and inter-assay CVs were 10.1 and $16.2 \%$ respectively. The $\mathrm{LH}$ concentration was determined directly in duplicate as $15 \mu \mathrm{l}$ plasma samples using a sensitive EIA for $\mathrm{LH}$ determination in bovine plasma based on the streptavidin-biotin technique as described by Mutayoba et al. (1990). The standard curve for LH ranged from 0.09 to $50 \mathrm{ng} / \mathrm{ml}$, and the $\mathrm{ED}_{50}$ of the assay was $3.1 \mathrm{ng} / \mathrm{ml}$. The intra- and inter-assay CVs were 8.3 and $11.2 \%$ respectively. The $\mathrm{GH}$ concentration was determined directly in duplicate as $15 \mu \mathrm{l}$ plasma samples using a sensitive EIA for $\mathrm{GH}$ determination in bovine plasma based on the streptavidin-biotin technique by a modification of the method previously described (Kawashima et al. 2007c). The standard curve for $\mathrm{GH}$ ranged from 0.78 to $100 \mathrm{ng} / \mathrm{ml}$, and the $\mathrm{ED}_{50}$ in this assay system was $6.2 \mathrm{ng} /$ $\mathrm{ml}$. The intra- and inter-assay CVs were 8.1 and $9.2 \%$ respectively. The EIA for total IGF1 was done as previously described (Kawashima et al. 2007a). Briefly, total IGF1 determination in plasma was performed by EIA after protein extraction by an acidethanol mixture $(87.5 \%$ ethanol and $12.5 \% 2 \mathrm{MHCl})$ to minimize interference with IGFBPs. The standard curve for IGF1 ranged from 0.39 to $50 \mathrm{ng} / \mathrm{ml}$, and the $\mathrm{ED}_{50}$ of the assay was $2.5 \mathrm{ng} / \mathrm{ml}$. The intra- and inter-assay CVs were 6.9 and $7.5 \%$ respectively.

\section{$L H$ and $G H$ pulse analysis}

Characteristics of the LH pulses were determined by the PULSAR computer program (Merriam \& Wachter 1982). The cut-off criteria for pulse determination G1, G2, G3, G4 and G5 were 3.0, 1.0, 0.8, 0.4 and 0.4 respectively (Yoshioka et al. 2001). The following pulse characteristics were calculated: 1) mean concentration, 2) basal concentration, 3) pulse amplitude, the difference between the peak and the preceding basal level, 4) pulse frequency, the mean number of pulses per $8 \mathrm{~h}$ and 5) AUC. GH pulses were determined for individual cows as described by Walters et al. (1984). Briefly, a pulse was defined as occurring when the value of the highest sample (peak) exceeded a preceding sample (basal) by at least four times the intra-assay CV of the EIA. There had to be at least one more value on the decreasing slope of a pulsatile hormone increase before basal concentrations were reached again. The amplitude was determined by subtracting the basal from the peak value. Mean and basal concentrations, pulse amplitude, pulse frequency and AUC were calculated.

\section{Statistical analysis}

In experiment 2, all data (follicular diameter, circulating hormone concentrations and characteristics of $\mathrm{LH}$ and $\mathrm{GH}$ pulses) were normalized to the day of observed follicular deviation. 
In both experiments 1 and 2, normal distribution of the data was assessed by Kolmogorov-Smirnov test. The data of follicular diameter in experiment 1 were evaluated by oneway ANOVA following Tukey-Kramer's test in both cows and heifers. The data of plasma concentrations of $\mathrm{P}_{4}, \mathrm{E}_{2}, \mathrm{FSH}$ and total IGF1, follicular diameter in experiment 2, and characteristics of the $\mathrm{LH}$ and $\mathrm{GH}$ pulses were analysed by two-way repeated-measures ANOVA. When an interaction between group and day was detected, mean values were calculated for each group and each sampling period, and the significant differences were analysed by Tukey-Kramer's test. If a main effect of the group was detected, significant differences between the CL-absent and CL-present groups were analysed using the Student's $t$-test throughout the experimental period. Results were presented as mean \pm s.E.M. Statistical significant was considered to be at $P<0.05$.

\section{Declaration of interest}

The authors declare that there is no conflict of interest that would prejudice the impartiality of this scientific work.

\section{Funding}

This study was supported by a Grant-in-Aid for Scientific Research (15658079) from the Japan Society for the Promotion of Science (JSPS), and the 21st Century COE Program (A-1) of the Ministry of Education, Culture, Sports, Science and Technology, Japan. K G H and K S are supported by JSPS Research Fellowships for Young Scientists (05)07002 to K G H and 05J00685 to K S). M M was a postdoctoral fellow supported by the 21 st Century COE Program.

\section{Acknowledgements}

The authors thank Dr K Okuda, Okayama University, Japan, for the generous donation of the $\mathrm{P}_{4}$ antiserum. The authors also thank Schering-Plough Animal Health K.K., for the generous donation of the Estrumate and Conceral. The authors are grateful to NIDDK for the supply of the bFSH, bLH and bGH.

\section{References}

Acosta TJ, Miyamoto A, Ozawa T, Wijayagunawardane MP \& Sato K 1998 Local release of steroid hormones, prostaglandin $\mathrm{E}_{2}$, and endothelin-1 from bovine mature follicles in vitro: effects of luteinizing hormone, endothelin-1, and cytokines. Biology of Reproduction 59 437-443.

Acosta TJ, Yoshizawa N, Ohtani M \& Miyamoto A 2002 Local changes in blood flow within the early and midcycle corpus luteum after prostaglandin $\mathrm{F}(2 \alpha)$ injection in the cow. Biology of Reproduction $\mathbf{6 6}$ 651-658.

Acosta TJ, Hayashi KG, Matsui M \& Miyamoto A 2005 Changes in follicular vascularity during the first follicular wave in lactating cows. Journal of Reproduction and Development 51 273-280.

Austin EJ, Mihm M, Evans AC, Knight PG, Ireland JL, Ireland JJ \& Roche JF 2001 Alterations in intrafollicular regulatory factors and apoptosis during selection of follicles in the first follicular wave of the bovine estrous cycle. Biology of Reproduction 64 839-848.
Austin EJ, Mihm M, Evans AC, Ireland JL, Ireland JJ \& Roche JF 2002 Effects of oestradiol and progesterone on secretion of gonadotrophins and health of first wave follicles during the oestrous cycle of beef heifers. Reproduction 124 531-541.

Bao B, Garverick HA, Smith GW, Smith MF, Salfen BE \& Youngquist RS 1997 Changes in messenger ribonucleic acid encoding luteinizing hormone receptor, cytochrome $\mathrm{P} 450$-side chain cleavage, and aromatase are associated with recruitment and selection of bovine ovarian follicles. Biology of Reproduction 56 1158-1168.

Beg MA, Bergfelt DR, Kot K, Wiltbank MC \& Ginther OJ 2001 Follicularfluid factors and granulosa-cell gene expression associated with follicle deviation in cattle. Biology of Reproduction 64 432-441.

Crowe MA, Kelly P, Driancourt MA, Boland MP \& Roche JF 2001 Effects of follicle-stimulating hormone with and without luteinizing hormone on serum hormone concentrations, follicle growth, and intrafollicular estradiol and aromatase activity in gonadotropin-releasing hormoneimmunized heifers. Biology of Reproduction 64 368-374.

Echternkamp SE, Spicer LJ, Gregory KE, Canning SF \& Hammond JM 1990 Concentrations of insulin-like growth factor-I in blood and ovarian follicular fluid of cattle selected for twins. Biology of Reproduction 43 8-14.

Evans AC \& Fortune JE 1997 Selection of the dominant follicle in cattle occurs in the absence of differences in the expression of messenger ribonucleic acid for gonadotropin receptors. Endocrinology 138 2963-2971.

Ginther OJ, Wiltbank MC, Fricke PM, Gibbons JR \& Kot K 1996 Selection of the dominant follicle in cattle. Biology of Reproduction $\mathbf{5 5}$ 1187-1194.

Ginther OJ, Kot K, Kulick LJ \& Wiltbank MC 1997 Emergence and deviation of follicles during the development of follicular waves in cattle. Theriogenology 48 75-87.

Ginther OJ, Bergfelt DR, Kulick LJ \& Kot K 1998 Pulsatility of systemic FSH and $\mathrm{LH}$ concentrations during follicular-wave development in cattle. Theriogenology 50 507-519.

Ginther OJ, Bergfelt DR, Beg MA \& Kot K 2001 a Follicle selection in cattle: role of luteinizing hormone. Biology of Reproduction 64 197-205.

Ginther OJ, Bergfelt DR, Beg MA \& Kot K $2001 b$ Effect of LH on circulating oestradiol and follicular fluid factor concentrations during follicle deviation in cattle. Reproduction 122 103-110.

Gong JG, Bramley TA \& Webb R 1993a The effect of recombinant bovine somatotrophin on ovarian follicular growth and development in heifers. Journal of Reproduction and Fertility 97 247-254.

Gong JG, McBride D, Bramley TA \& Webb R $1993 b$ Effects of recombinant bovine somatotrophin, insulin-like growth factor-I and insulin on the proliferation of bovine granulosa cells in vitro. Journal of Endocrinology $13967-75$.

Gong JG, McBride D, Bramley TA \& Webb R 1994 Effects of recombinant bovine somatotrophin, insulin-like growth factor-I and insulin on bovine granulosa cell steroidogenesis in vitro. Journal of Endocrinology 143 157-164.

Gumen A \& Wiltbank MC 2005 Follicular cysts occur after a normal estradiol-induced $\mathrm{GnRH} / \mathrm{LH}$ surge if the corpus hemorrhagicum is removed. Reproduction 129 737-745.

Hampton JH, Bader JF, Lamberson WR, Smith MF, Youngquist RS \& Garverick HA 2004 Gonadotropin requirements for dominant follicle selection in GnRH agonist-treated cows. Reproduction 127 695-703.

Hayashi KG, Matsui M, Acosta TJ, Kida K \& Miyamoto A 2006 Effect of the dominant follicle aspiration before or after luteinizing hormone surge on the corpus luteum formation in the cow. Journal of Reproduction and Development 52 129-135.

Jimenez-Krassel F, Binelli M, Tucker HA \& Ireland JJ 1999 Effect of longterm infusion with recombinant growth hormone-releasing factor and recombinant bovine somatotropin on development and function of dominant follicles and corpora lutea in Holstein cows. Journal of Dairy Science 82 1917-1926.

Kawashima C, Sakaguchi M, Suzuki T, Sasamoto Y, Takahashi Y, Matsui M \& Miyamoto A 2007 a Metabolic profiles in ovulatory and anovulatory primiparous dairy cows during the first follicular wave postpartum. Journal of Reproduction and Development 53 113-120.

Kawashima C, Kida K, Hayashi KG, Amaya Montoya C, Kaneko E, Matsunaga N, Shimizu T, Matsui M, Miyake Y, Schams D et al. 2007b 
Changes in plasma metabolic hormone concentrations during the ovarian cycles of Japanese black and holstein cattle. Journal of Reproduction and Development 53 247-254.

Kawashima C, Fukihara S, Maeda M, Kaneko E, Montoya CA, Matsui M, Shimizu T, Matsunaga N, Kida K, Miyake Y et al. 2007c Relationship between metabolic hormones and ovulation of dominant follicle during the first follicular wave post-partum in high-producing dairy cows. Reproduction 133 155-163.

Kinder JE, Kojima FN, Bergfeld EG, Wehrman ME \& Fike KE 1996 Progestin and estrogen regulation of pulsatile $\mathrm{LH}$ release and development of persistent ovarian follicles in cattle. Journal of Animal Science $\mathbf{7 4}$ 1424-1440.

Kirby CJ, Smith MF, Keisler DH \& Lucy MC 1997 Follicular function in lactating dairy cows treated with sustained-release bovine somatotropin. Journal of Dairy Science 80 273-285.

Kulick LJ, Kot K, Wiltbank MC \& Ginther OJ 1999 Follicular and hormonal dynamics during the first follicular wave in heifers. Theriogenology 52 913-921.

Kulick LJ, Bergfelt DR, Kot K \& Ginther OJ 2001 Follicle selection in cattle: follicle deviation and codominance within sequential waves. Biology of Reproduction 65 839-846.

Landefeld TD \& Suttie JM 1989 Changes in messenger ribonucleic acid concentrations and plasma levels of growth hormone during the ovine estrous cycle and in response to exogenous estradiol. Endocrinology 125 1474-1478.

Lopez H, Sartori R \& Wiltbank MC 2004 Reproductive hormones and follicular growth during development of one or multiple dominant follicles in cattle. Biology of Reproduction 72 788-795.

Lucy MC 2000 Regulation of ovarian follicular growth by somatotropin and insulin-like growth factors in cattle. Journal of Dairy Science $\mathbf{8 3}$ 1635-1647.

Manikkam M, Calder MD, Salfen BE, Youngquist RS, Keisler DH \& Garverick HA 2001 Concentrations of steroids and expression of messenger RNA for steroidogenic enzymes and gonadotropin receptors in bovine ovarian follicles of first and second waves and changes in second wave follicles after pulsatile LH infusion. Animal Reproduction Science 67 189-203.

Merriam GR \& Wachter KW 1982 Algorithms for the study of episodic hormone secretion. American Journal of Physiology 243 E310-E318.

Miyamoto A, Okuda K, Schweigert FJ \& Schams D 1992 Effects of basic fibroblast growth factor, transforming growth factor-beta and nerve growth factor on the secretory function of the bovine corpus luteum in vitro. Journal of Endocrinology 135 103-114.

Mutayoba BM, Meyer HH, Schams D \& Schallenberger E 1990 Development of a sensitive enzyme immunoassay for $\mathrm{LH}$ determination in bovine plasma using the streptavidin-biotin technique. Acta Endocrinologica 122 227-232.

Pfaffl MW, Daxenberger A, Hageleit M \& Meyer HH 2002 Effects of synthetic progestagens on the mRNA expression of androgen receptor, progesterone receptor, oestrogen receptor alpha and beta, insulin-like growth factor-1 (IGF-1) and IGF-1 receptor in heifer tissues. Journal of Veterinary Medicine. A, Physiology, Pathology, Clinical Medicine 49 $57-64$.
Rivera GM \& Fortune JE 2001 Development of codominant follicles in cattle is associated with a follicle-stimulating hormone-dependent insulin-like growth factor binding protein-4 protease. Biology of Reproduction 65 112-118.

Rivera GM \& Fortune JE 2003 Proteolysis of insulin-like growth factor binding proteins -4 and -5 in bovine follicular fluid: implications for ovarian follicular selection and dominance. Endocrinology 144 2977-2987.

Simpson RB, Chase CC Jr, Spicer LJ, Carroll JA, Hammond AC \& Welsh TH Jr 1997 Effect of exogenous estradiol on plasma concentrations of somatotropin, insulin-like growth factor-I, insulin-like growth factor binding protein activity, and metabolites in ovariectomized Angus and Brahman cows. Domestic Animal Endocrinology 14 367-380.

Sirotkin AV \& Makarevich AV 1999 GH regulates secretory activity and apoptosis in cultured bovine granulosa cells through the activation of the cAMP/protein kinase A system. Journal of Endocrinology 163 317-327.

Spicer LJ \& Echternkamp SE 1995 The ovarian insulin and insulin-like growth factor system with an emphasis on domestic animals. Domestic Animal Endocrinology 12 223-245.

Spicer LJ, Alpizar E \& Echternkamp SE 1993 Effects of insulin, insulin-like growth factor I, and gonadotropins on bovine granulosa cell proliferation, progesterone production, estradiol production, and (or) insulinlike growth factor I production in vitro. Journal of Animal Science $\mathbf{7 1}$ 1232-1241.

Walters DL, Schams D \& Schallenberger E 1984 Pulsatile secretion of gonadotrophins, ovarian steroids and ovarian oxytocin during the luteal phase of the oestrous cycle in the cow. Journal of Reproduction and Fertility 71 479-491.

Watanabe H, Miyamoto A \& Fukui Y 1997 A competitive enzyme immunoassay for follicle-stimulating hormone in ovine plasma using biotin-streptavidin amplification. Reproduction, Fertility, and Development 9 597-601.

Wijayagunawardane MP, Miyamoto A, Cerbito WA, Acosta TJ, Takagi M \& Sato K 1998 Local distributions of oviductal estradiol, progesterone, prostaglandins, oxytocin and endothelin- 1 in the cyclic cow. Theriogenology 49 607-618.

Xu Z, Garverick HA, Smith GW, Smith MF, Hamilton SA \& Youngquist RS 1995 Expression of follicle-stimulating hormone and luteinizing hormone receptor messenger ribonucleic acids in bovine follicles during the first follicular wave. Biology of Reproduction 53 951-957.

Yonezawa T, Mogi K, Li JY, Sako R, Yamanouchi K \& Nishihara M 2005 Modulation of growth hormone pulsatility by sex steroids in female goats. Endocrinology 146 2736-2743.

Yoshioka K, Suzuki C, Arai S, Iwamura S \& Hirose H 2001 Gonadotropinreleasing hormone in third ventricular cerebrospinal fluid of the heifer during the estrous cycle. Biology of Reproduction 64 563-570.

Received 25 October 2007

First decision 4 December 2007

Revised manuscript received 7 August 2008

Accepted 20 August 2008 